\title{
Prevalence of microorganisms of hygienic interest in an organized abattoir in Mumbai, India
}

\author{
Sudhakar Bhandare, Ashish M. Paturkar, Vikas S. Waskar and Ravindra J. Zende \\ Department of Veterinary Public Health, Bombay Veterinary College, Parel, Mumbai-12, India
}

\begin{abstract}
Background: The magnitude of food-borne illnesses in India is unknown because of lack of surveillance networks. Monitoring the prevalence of food-borne pathogens and indicators of contamination in primary production at abattoirs is imperative for creating a data bank and for effective control of such pathogens before they enter the food chain.

Methodology: Microorganisms of hygienic interest were screened for their prevalence at Deonar Abattoir, Mumbai. Swab samples from 96 sheep/goat carcass sites were collected and analyzed for Staphylococcus spp., Bacillaceae, Clostridiaceae and Enterobacteriaceae.

Results: Average Staphylococcus aureus and Staphylococcus epidermidis counts were $3.15 \pm 0.18$ and $3.46 \pm 0.17 \log _{10} \mathrm{CFU} / \mathrm{cm}^{2}$, respectively. Bacillus cereus, Bacillus subtilis and Clostridium spp. counts were $3.10 \pm 0.08,3.41 \pm 0.19$ and $0.76 \pm 0.06 \log _{10} \mathrm{CFU} / \mathrm{cm}^{2}$, respectively. The Escherichia coli count was $3.54 \pm 0.06$ and the Klebsiella aerogenes count was $3.22 \pm 0.22 \log _{10} \mathrm{CFU} / \mathrm{cm}^{2}$. Counts for Proteus vulgaris and Proteus mirabilis were $3.44 \pm 0.14 \log _{10} \mathrm{CFU} / \mathrm{cm}^{2}$ and $3.71 \pm 0.12 \log 10 \mathrm{CFU} / \mathrm{cm}^{2}$, respectively. S. epidermidis had the highest percentage prevalence at (41.6\%), followed by K. aerogenes (31.9\%), B. subtilis (28.2\%) and P. vulgaris (23.6\%). Salmonella spp. were not isolated.

Conclusions: The data demonstrate high prevalence and diversity of micro flora on carcasses in the primary Indian production facility, which might be attributed to either human handling or improper dressing especially during evisceration process. Appropriate training for personal and production hygiene is essential for workers in Indian meat production facilities.
\end{abstract}

Key words: microorganisms of hygienic interest; sheep/goat carcasses; abattoir; prevalence

J Infect Dev Ctries 2010; 4(7):454-458.

(Received 3 March 2010 - Accepted 30 March 2010)

Copyright $\odot 2010$ Bhandare $e t$ al. This is an open-access article distributed under the Creative Commons Attribution License, which permits unrestricted use, distribution, and reproduction in any medium, provided the original work is properly cited.

\section{Introduction}

Food-borne diseases are a threat to public health worldwide. The repercussions are not only health related but also have economic ramifications from the loss of business over food safety issues. In the United States of America (USA), 60\% of cases requiring hospitalization are caused by the food-borne bacteria [1], but in developing countries related data is not available because of a lack of precise health-care infrastructure and data management. It is estimated that annually about 1.8 million children in developing countries succumb to death from acute diarrhoeal illnesses, with food or water being the major causes of many of these illnesses [2]. Chugh [3] has identified the emerging and reemerging zoonotic, food-borne and waterborne diseases as well as the diseases caused by multidrug resistant organisms as the major public health threats in India. However, the magnitude of food-borne illnesses in India is unknown due to the lack of a coordinated surveillance network.
As far as foods of animal origin are concerned, India is the largest milk producer in the world [4]; however, in spite of the potential from the large livestock population, meat production is below capacity but is building. The total meat processing capacity in India is over one million tons per annum, of which 40-50 percent is utilized [5]; thus there is tremendous scope in this sector. Given the present attention from the government and private entrepreneurs, the future of the meat industry in India looks prosperous; however, much work is needed in maintaining quality assurance to prevent food-borne diseases. Monitoring the prevalence of microorganisms of hygienic interest in primary production at abattoirs is imperative for creating a data bank and for effective control of such pathogens before they further enter the food chain. The present study was undertaken at an organized abattoir in Mumbai city to determine the prevalence of microorganisms of hygienic interest. 


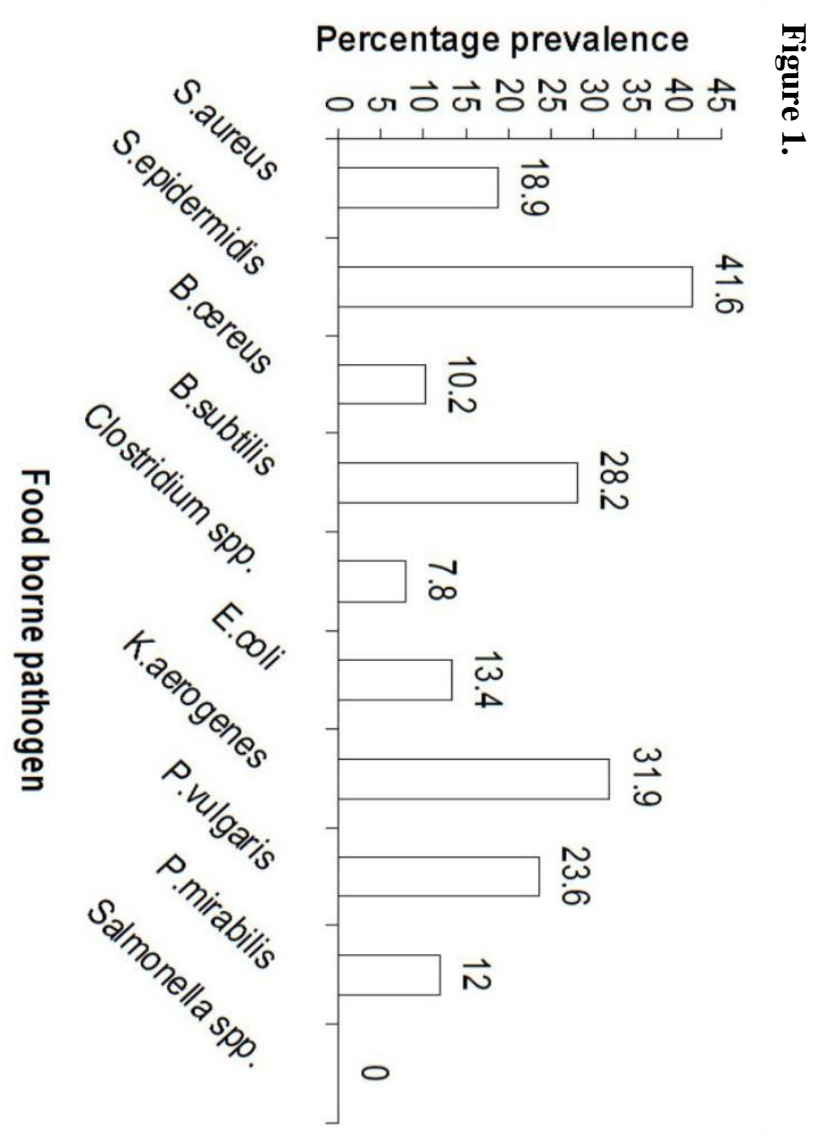

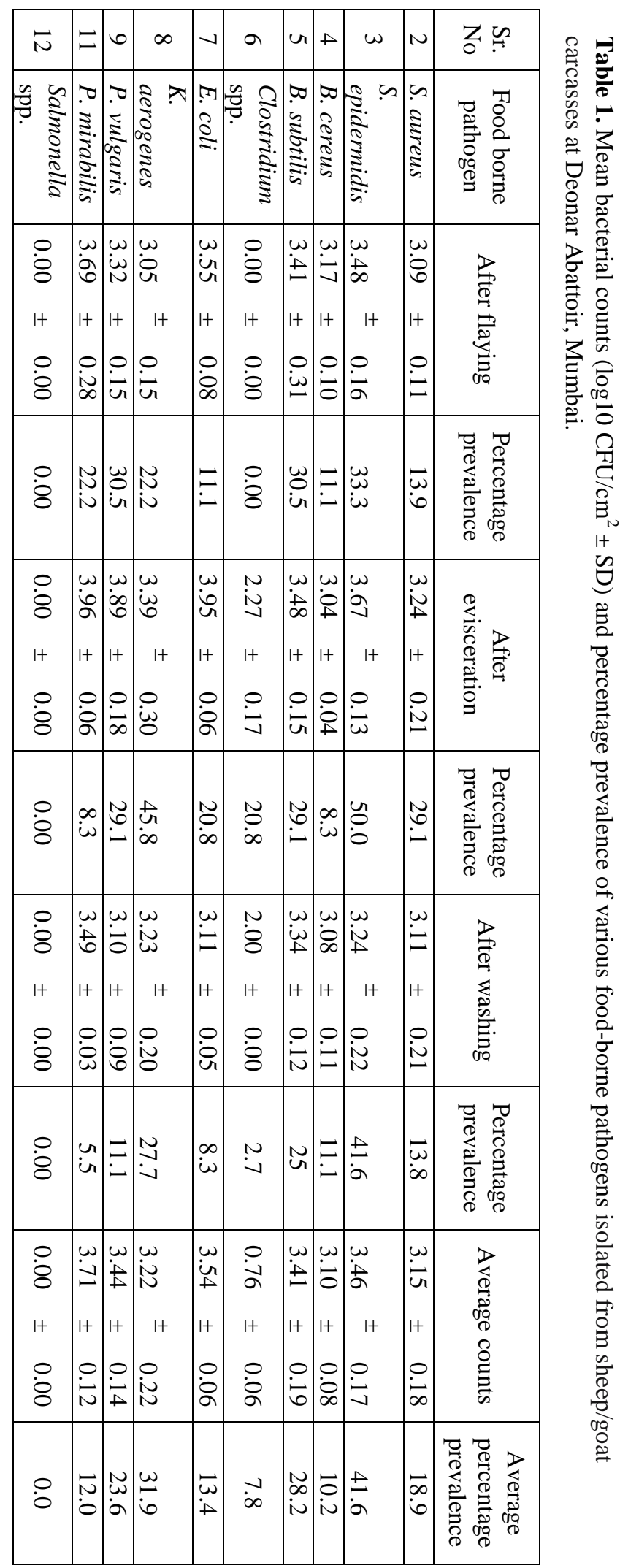




\section{Materials and methods}

All the media used were dehydrated and purchased from HiMedia laboratories, Mumbai, India. Swab samples were collected from sites on sheep and goat carcasses after various slaughter operations (flaying, evisceration and washing) at an organised abattoir (i.e., a modern, mechanised and export-oriented abattoir with proper infrastructure and skilled manpower to slaughter a large number of animals, which follows the safety specifications given by the Meat and Meat Product Order of 1973 issued by the Directorate of Marketing and Inspection, Government of India) at Deonar, Mumbai. A total of 96 samples were taken at the abattoir from six different carcasses on six occasions (Table 1) from the neck, shoulder, brisket, loin, flank and rump after flaying and washing. After evisceration samples were collected from the brisket and rib medial, brisket and rib lateral, and loin and flank regions. Carcass sites were sampled by the swab technique. Briefly, an area of $100 \mathrm{~cm}^{2}$ was marked with a sterile frame of $10 \mathrm{~cm} \times 10 \mathrm{~cm}$ for each site on the carcass. Sterile cotton wool swabs (3 $\mathrm{cm}$ long and $1 \mathrm{~cm}$ in diameter) held by wooden sticks moistened with $0.1 \%$ peptone were rubbed on the sites continuously for 30 seconds and transferred to a screw-capped test tube containing $10 \mathrm{ml}$ of sterile maintenance medium $(0.85 \% \mathrm{NaCl}$ and $0.1 \%$ peptone). The screw-capped test tubes were brought to the laboratory in a thermos flask containing ice and processed immediately.

Test tubes containing swabs were shaken on a vortex mixer for 30 seconds for uniform distribution of microorganisms. Tenfold serial dilution of all the samples was prepared using sterile normal saline solution (NSS). Then the samples were processed for viable counting.

Food-borne organisms were enumerated using various selective and differential media employing spread or pour plate techniques with $0.1 \mathrm{ml}$ inoculum from $10^{-2}$ and $10^{-3}$ dilutions decided on the basis of the results of pilot studies used to pre-estimate the microbial load at each abattoir. Differential count plates were incubated for 24-48 hours and, with the exception of some media for Clostridia and Salmonella, were incubated at $37^{\circ} \mathrm{C}$. Vogel Johnson plates were used for isolation and enumeration of Staphylococcus spp. Egg yolk agar and blood agar were used for isolation and enumeration of Bacillus spp. and B. cereus isolation agar (Code M833) was used for isolation and identification of $B$. cereus in suspected cases. Clostridium species were isolated by wax overlay anaerobic technique upon Sodium Polymyxin Sulphadiazine (SPS) agar incubated at $44 \mathrm{C}$ for 24 hours.

Various members of the family Enterobacteriaceae were isolated and enumerated using MacConkey agar with crystal violet. Eosin Methylene Blue agar was employed for isolation and identification of $E$. coli showing typical metallic sheen. To isolate Salmonella spp. swab samples were homogenised in $225 \mathrm{ml}$ buffered peptone water and pre-enriched at $37^{\circ} \mathrm{C}$ for 24-48 hours; then $1 \mathrm{ml}$ of culture was transferred to 10 $\mathrm{ml}$ of Selenite Cystine broth (enrichment medium) and incubated at $44^{\circ} \mathrm{C}$ for 18 hours. Selective plating was done on Brilliant Green Sulpha agar and incubated $43^{\circ} \mathrm{C}$ for 24 hours.

Two to three characteristic colonies of each bacterium were further subjected to purification, identification, and characterization. Microscopic examination was conducted on smears stained by modified Gram's staining as described by Beveridge [6]. Characterisation and identification of organisms was done according to Barrow and Feltham [7] and Cheesbrough [8]. All counts were converted to $\log _{10}$ $\mathrm{CFU} / \mathrm{cm}^{2}$ along with standard deviation and percentage prevalence was calculated.

\section{Results}

The results obtained are shown in Table 1 and Figure 1. The Staphylococcus spp. isolated were Staphylococcus aureus and Staphylococcus epidermidis with their average counts as $3.15 \pm 0.18$ and $3.46 \pm 0.17 \log _{10} \mathrm{CFU} / \mathrm{cm}^{2}$, respectively. From the family Bacillaceae, Bacillus cereus and Bacillus subtilis were isolated with their average counts as $3.10 \pm 0.08$ and $3.41 \pm 0.19 \log _{10} \mathrm{CFU} / \mathrm{cm}^{2}$, respectively. The counts of Clostridium spp. from family Clostridiaceae were $0.76 \pm 0.06 \quad \log _{10}$ $\mathrm{CFU} / \mathrm{cm}^{2}$. Organisms from the Enterobacteriaceae family that were isolated include Escherichia coli, Klebsiella aerogenes, Proteus vulgaris, Proteus mirabilis, but Salmonella spp. E. coli and $K$. aerogenes were recovered at $3.54 \pm 0.06$ and $3.22 \pm$ $0.22 \log _{10} \mathrm{CFU} / \mathrm{cm}^{2}$, respectively, while counts of $P$. vulgaris and $P$. mirabilis were $3.44 \pm 0.14$ and $3.71 \pm$ $0.12 \log _{10} \mathrm{CFU} / \mathrm{cm}^{2}$, respectively. It was noticed that the differential counts were increased after the evisceration process and were reduced after washing of the carcasses (Table 1).

The highest percentage prevalence (Figure 1) noticed was that of S. epidermidis (41.6\%), followed by $K$. aerogenes (31.9\%), B. subtilis (28.2\%), and $P$. vulgaris $(23.6 \%)$. Lower percentage prevalences 
were seen for Clostridium spp. (7.8\%), B. cereus (10.2\%) and P. mirabilis (12\%). The prevalence of $S$. aureus was $18.9 \%$, while that of E. coli was $13.4 \%$.

\section{Discussion}

The present data represent the prevalence of a diversity of microflora on carcasses in the primary Indian production facility. Similar to our study, Narasimha Rao and Ramesh [9] observed average counts for Staphylococcus spp. as $1.63 \quad \log _{10}$ $\mathrm{CFU} / \mathrm{cm}^{2}$. Borse et al. [10] also isolated Bacillus spp., Micrococcus spp., Staphylococcus spp. and Enterobacter spp. as predominant flora in sheep carcasses and Vijaya Rao et al. [11] recovered Staphylococcus (44.6\%), Enterobacteriacae (9.2\%) and Bacillus (4.2\%) as predominant organisms from fresh mutton. McDowell et al. [12] reported similar microflora at brisket, forequarters and rear-quarters with $8 \%$ Staphylococcus aureus, $13 \%$ other Staphylococci, and 14\% Bacillus spp. Krustch [13] isolated Clostridium spp. from $4 \%$ swab samples of sheep carcass surfaces, which is almost in accordance with the observations of the present study. Sierra et al. [14] found $E$. coli as the main pathogen in swabs taken from lamb carcasses, while Enterobacter, Klebsiella and Serratia spp. were detected in lower numbers. Also, Biss and Hathaway [15] found E. coli from $21.37 \%$ of lamb carcass surfaces.

The high incidence of Staphylococcus spp. in this study is indicative of a contamination due to human handling as these organisms are the commensals of human skin and mucosal surfaces. Bendahou et al. [16] mention that the enterotoxin-producing $S$. aureus can be dangerous and harmful to human health. Similarly, other major prevalent Enterobacteriaceae family organisms such as K.aerogenes, B.subtilis and $P$. vulgaris are also inhabitants of the respiratory and intestinal tract of humans as well as animals. Thus their prevalence may be attributed to either human handling or improper dressing, especially during the evisceration process. The infections caused by such Gram-negative bacteria are a worldwide public health problem [17]. Per European Commission [18] norms, Enterobacteriaceae counts greater than $3.0 \log _{10}$ $\mathrm{CFU} / \mathrm{cm}^{2}$ are unacceptable but the present study shows higher counts than the prescribed limits even after the washing operation.

It is encouraging that Salmonella spp. could not be detected in this study. Salmonella is a common cause of bacterial food-borne gastroenteritis in many countries worldwide and in India it is known to be endemic [19]. The overall annual incidence of food- borne salmonellosis in India is nearly 6 per 1,000 inhabitants [20]. The most commonly implicated serotypes for disease outbreaks are Salmonella enterica serotype Typhimurium and Salmonella enterica serotype Enteritidis [21]. Non-typhoid salmonellosis originating from foods of animal origin is an emerging infection in India and is noted to be an increasing trend [22].

Although the hazard analysis critical control point system (HACCP) is implemented at the Deonar Abattoir in its sheep/goat unit, with the exception of the absence of Salmonella spp., the occurrence of the other aforementioned microorganisms of hygienic interest is a serious concern. To evaluate the effectiveness of the food safety programs, baseline studies are needed to determine levels of indicator organisms and prevalence of pathogens [23]. The farm-to-fork approach is advised in food safety management and detection of such food-borne pathogens and indicators of contamination at an abattoir makes it necessary to also look back at the farms to reduce the microbial load. India does not have organized farming practices for meat production with appropriate veterinary input; thus it is difficult to receive the animals with least microbial load at the lairages. Management practices such as pre-slaughter fasting at lairages with access to water, along with the maintenance of strict hygiene and sanitation at the slaughterhouses, can help to reduce the microbial load of carcasses. Appropriate training for personal and production hygiene is highly essential for the people working in Indian meat production facilities.

\section{Acknowledgments}

The research grants provided by the Indian Council of Agricultural Research, New Delhi, are thankfully acknowledged.

\section{References}

1. Mead PS, Slutsker L, Dietz V, McCaig LF, Bresee JS, Shapiro C, Griffin PM, and Tauxe RV (1999) Food-related illness and death in the United States. Emerg Infect Dis 5: 607-625.

2. World Health Organization (2005) The World Health Report 2005 - Making every mother and child count. Geneva, Switzerland, 2005.

3. Chugh TD (2008) Emerging and re-emerging bacterial diseases in India. J Biosci 33: 549-555.

4. FAO (2007) Food and Agriculture Organisation: Statistical database: $2007 . \quad$ Available: http://faostat.fao.org/site/339/default.aspx. Accessed 26/1/2010.

5. APEDA (2009) Agricultural and Processed Food Products Export Development Authority, Govt. of India: Database: $2009 . \quad$ Available: http://apeda.com/apedawebsite/SubHead_Products/ Processed_Meat.htm. Accessed 26/1/2010. 
6. Beveridge TJ (2001) "Use of the gram stain in microbiology". Biotechnic and Histochemistry 76: 111-118.

7. Barrow GI and Feltham RKA (2003) In Cowan and Steel's Manual for the Identification of Medical Bacteria (3rd ed), 1st paperback edition. Cambridge University Press, Cambridge, pp. 50-150.

8. Cheesbrough M (2006) District Laboratory Practice in Tropical Countries (Part II), $2^{\text {nd }}$ Edition. Cambridge University Press, Cambridge.

9. Narsimha Rao D and Ramesh BS (1992) The microbiology of sheep carcasses processed in a modern abattoir. Meat Science 32: 425-436.

10. Borse PD, Sherikar AT, Waskar VS and Paturkar AM (1998) Microbiological analysis of carcass sites in sheep slaughtered at Deonar abattoir. Indian Veterinary Journal 75: 141-143.

11. Vijaya Rao D, Bhagirathi B and Sharma TR (1983) Fluctuations in the quantitative predominance of bacterial groups in fresh and stored mutton. J Food Sci and Technol 20: 277-281.

12. McDowell DA, Hobson I, Strain JJ and Owena JJ (1986) Bacterial microflora of chill stored beef carcasses. Environmental Health 94: 65 - 68.

13. Krustch HW (1989) Bacteriological testing unit at Nuremberg slaughterhouse: Results of 10 years. Fleischwirtschaft 69: 1556 - 1558 .

14. Sierra M, Gonzalez-Fandos E, Garcia MC, Garcia ML and Moreno B (1996) Application of this system of hazard analysis and critical control points (HACCP) in the lamb processing line. Alimentaria 270: 39 - 42.

15. Biss ME and Hathaway SC (1998) A HACCP based approach to hygienic slaughter and dressing of lamb carcasses. NewZealand Vet J 46: 167 -172.

16. Bendahou A, Abid M, Bouteldoun N, Catelejine D and Lebbadi M (2009) Enterotoxigenic coagulase positive Staphylococcus in milk and milk products, lben and jben, in northern Morocco. J Infect Developing Countries 3: 169176.

17. Moehario LH, Tjoa E, Kiranasari A, Ningsih I, Rosana Y and Karuniawati A (2009) Trends in antimicrobial susceptibility of Gram-negative bacteria isolated from blood in Jakarta from 2002 to 2008. J Infect Developing Countries 3: 843-848.

18. European Commission (2001) Applying microbiological criteria to excised-sample test results. Official Journal of the European Communities 165: 51-52.

19. Tankhiwale SS, Agrawal G and Jalgoankar SV (2003) An unusually high occurrence of Salmonella enterica serotype Paratyphi A in patients with enteric fever. Indian Journal of Medical Research 117: 10-12

20. Henson S (2003) The Economics of food safety in Developing Countries. ESA Working Paper No. 03-19, December 2003. (www.fao.org/es/esa) (Accessed on 28/03/2010)

21. Sadeyen JR, Trotereau J, Velge P, Marly J, Beaumont C, Burrow PA, Bumstead N and Lalmanach AC (2004) Salmonella carrier state in chicken: Comparison of expression of immune response genes between susceptible and resistant animals. Microbes and Infection 6: 1278-1286.

22. Shahane V, Muley V, Kagal A and Bharadwaj R (2007) Non-typhoid Salmonellosis: Emerging infection in Pune? Indian Journal of Medical Microbiology 25: 173-174.

23. Bohaychuk VM, Checkley SL, Gensler GE and Barrios PR (2009) Microbiological baseline study of poultry slaughtered in provincially inspected abattoirs in Alberta, Canada. Canadian Veterinary Journal 50: 173-178.

\section{Corresponding Author}

Sudhakar Bhandare

Assistant Professor

Department of Veterinary Public Health

Bombay Veterinary College

(Maharashtra Animal and Fishery Sciences University)

Parel, Mumbai-12, India

Phone: 0091-9423754188

Fax: 0091-022-24172301

Email: vetsudhakar@bristolalumni.org.uk

Conflict of interests: No conflict of interests is declared. 